\title{
Respek and Other Urban Vila Keywords
}

Respek et autres mots-clés du Port-Vila urbain

\section{Lamont Lindstrom}

Translator. Alexis Black and Christine Jourdan

\section{OpenEdition \\ Journals}

Electronic version

URL: http://journals.openedition.org/jso/7849

DOI: $10.4000 /$ jso. 7849

ISSN: $1760-7256$

\section{Publisher}

Société des océanistes

\section{Printed version}

Date of publication: 15 December 2017

Number of pages: 23-36

ISSN: 0300-953x

\section{Electronic reference}

Lamont Lindstrom, "Respek and Other Urban Vila Keywords", Journal de la Société des Océanistes [Online], 144-145 | 2017, Online since 15 December 2019, connection on 15 March 2021. URL: http:// journals.openedition.org/jso/7849 ; DOl: https://doi.org/10.4000/jso.7849

This text was automatically generated on 15 March 2021.

\section{cc) (†) $९$}

Journal de la société des océanistes est mis à disposition selon les termes de la Licence Creative Commons Attribution - Pas d'Utilisation Commerciale - Pas de Modification 4.0 International. 


\title{
Respek and Other Urban Vila Keywords
}

\author{
Respek et autres mots-clés du Port-Vila urbain \\ Lamont Lindstrom \\ Translation : Alexis Black and Christine Jourdan
}

Some words are keys, opening up sharper awareness of elemental cultural and social formations, or so proposed British scholar Raymond Williams when preparing his 1958 historical overview of changing notions of Culture and Society. Williams later, in 1976, published a compendium of 110 such keywords, running from 'aesthetic' to 'work'. We share, so said Williams, a keyword vocabulary and we use this

"when we wish to discuss many of the central processes of our common life"

(Williams, 1976: 12)

Williams subsequently extended his keyword list, as have others (Bennett, Grossburg and Morris, 2005). Anthropologists, too, have focused on prominent keywords to unlock insight into this or that culture. Kim (2005) examined 15 Korean keywords (e.g., 'crying', 'spoon', 'fire'); Wierzbicka (1997) compared English speakers with Russian, Polish, German, and Japanese who share important keywords (e.g., 'friendship', 'freedom', 'homeland') although the local connotations of these diverge.

Williams argued that keywords signify in "material and historical ways" (1976: 20); that is, words shape but are also shaped by everyday struggle and experience. Keywords and their shifting significations can reveal what's on people's minds. My own interest in keywords was sparked by interviewing friends from Tanna, one-time villagers many of whom now live in urban Port Vila settlements (Lindstrom, 2011a-b). ${ }^{1}$ In these interviews, the same words kept popping up. When reflecting on life in town, people offered geographic comparison between town life and island life, which overlapped a temporal frame of life today versus life before. Beyond town and city, emergent urbanity is fundamentally shaping the development of comprehensive national cultures in Vanuatu and across Melanesia. Town life and experience, no longer the 
idyllic village, are generating shared experience and national identity, shaping what it means to be ni-Vanuatu, or a Solomon Islander, or a citizen of Papua New Guinea.

When recalling migrant experience, a number of common keywords peppered people's stories in which they compared village and urban life. As people cultivate new urban lives, they have also elaborated words and terms to discuss this. To assess their lives in town, Tanna friends repeatedly employed a number of ear-catching terms. Like Raymond Williams, I take these words to be keys into urban life in Port Vila that reflect people's material and historical experiences. Keywords open up a perspective on emergent Melanesian urbanism. In that I interviewed people using Nafe (Kwamera) language of southeast Tanna, these words came sometimes from that language, or were Bislama (Vanuatu's lingua franca Pidgin English) words that narrators code-mixed into the conversation, often alternating between a Nafe word and its Bislama equivalent. My selection of words relied on basic narrative analysis that suggested a word might be "key" based on its occurrence, salience, meaningful context, and also speaker prosody, rather than a simple quantitative frequency score.

5 Notable urban keywords I pulled from migrant narratives included jalus ('jealousy, jealous', etet in Nafe although this more finely means 'jealously guard'); noes ('noise', taragaru in Nafe); sekiuriti ('security', particularly a security guard); mobael (which, in Vanuatu, refers both to telephone and to Vanuatu's para-military force); and fri ('freedom' and also 'free', auar in Nafe if this refers to cash-free consumption). One might add to this list tanak, the fairly recent Nafe calque on 'thanks' or Bislama tangkyu. Wantok ('same language' or 'comrade') is another Melanesian urbanism (Levine and Levine, 1979: 70; Schram, 2015), although one more common in Port Moresby than Port Vila. The principal keyword I consider here was one of my friends' most useful terms to evaluate city life. Urban experience frequently provoked issues of respek (or rispek, in Bislama; nisiaiien in $\mathrm{Nafe}^{2}$ ). And when evoking respek, people mostly said that they wanted and needed more of this (see Lerche, 2008).

\section{Respek}

6 I leave it to others to compose a genealogy of respect, but my guess is that sharpening ethno and gender identity politicking nearly everywhere has significantly boosted the term's utility, including in socially complex post-colonial Melanesian towns. Williams and his successors did not include 'respect' among their catalogs of contemporary keywords but future scholars might well do so. Google's Ngrams indicate that literary uses of the phrase "demand respect" about doubled between 1960 and 2008. Across the twentieth-century, the upsurge of civil rights discourse, feminism (condensed into Aretha Franklin's mega-hit song R-E-S-P-E-C-T), multiculturalism, identity politics, as well as globalization, urban migration, clashes of civilization, religious conflict, and more have emboldened many of us to demand respect, or to complain of our lack thereof. Ethnographers of inner city communities have documented increasingly noisy respect claims (e.g., in Philippe Bourgois' In Search of Respect, 2003); as have sociologists concerned with modernity's rocky interrelationships. Sara Lawrence-Lightfoot, for one, observed that "every morning the newspaper contains a story that echoes the words of Aretha's anthem: pleas for respect from people who have been violated, neglected, or ignored by loved ones, acquaintances, strangers, or public figures" (Lawrence- 
Lightfoot, 1999: 8). The onetime American comic Rodney Dangerfield's catchphrase, "I don't get no respect," still speaks for many.

7 Melanesia's growing multiethnic, multilingual, and economically stratified urban centers are respect microcosms. Many of the same forces that produce respect anxiety elsewhere churn here, too. Port Vila's population is booming, rising from 29,000 in 1999 to over 50,000 today. Bislama dictionaries and handbooks suggest that respect-worry has amplified alongside urbanization which, in Vanuatu, rose significantly immediately before and after that country's 1980 independence (Haberkorn, 1989: 9-14). The word respek appears in Crowley's 1990 Bislama dictionary, but Guy does not include this in his 1974 Bislama handbook.

8 Tanna urban migrants have enthusiastically taken up the word. They bemoan respect's absence and they evoke disrespect to explain conflict and disappointment. Attending to migrant respect talk helps uncover roots of urban complaints as well as concepts of persons and what they deserve. In the West, respect frames proper consideration of persons (like Bourgois' crack cocaine dealers in the Barrio who are in search of "dignity and fulfillment" (2003: 324)). Respect also signifies appropriate deference to authority, tradition, or institutions. In Vanuatu, local "house-girls" (female domestics), for instance, say that they crave respect, but not equality, from white employers: "The central issue for house-girls, then, is not one of inequality/equality, nor one of 'difference'; rather, it is an issue of respect. What house-girls want, and what housegirls need, is for employers to respect their feelings and dignity as human beings" (Kraemer and Rodman, 2005: 148). Respek talk in Vanuatu frequently evokes appropriate, typically hierarchical relationships more than it stakes claims for individual equality.

9 Much ink has been spilled about the celebrated, or infamous, partible dividual in Melanesia (Strathern, 1988: 34). Different regimes of personhood must shade local appreciation of discursive strategies and significance of respect. For several decades, now, ethnographers have kept eyes peeled for any upsurge in possessive individualism in Melanesia, especially in urban areas where migrants more easily disconnect from their village kin networks (Gewertz and Errington, 1999: 42). Given porous boundaries between town and village throughout Melanesia, it is unclear how far many urban migrants have solidified their individualism and boosted their demands for personal dignity and a respected status, sloughing off their old kin and place ties. For additional clues to changing urban personhood, thus, one might listen carefully to migrant discourses about respect.

\section{Respect in Urban Settlements}


Figure 1. - Tanna migrants in Blacksands settlement, Port Vila, 2010

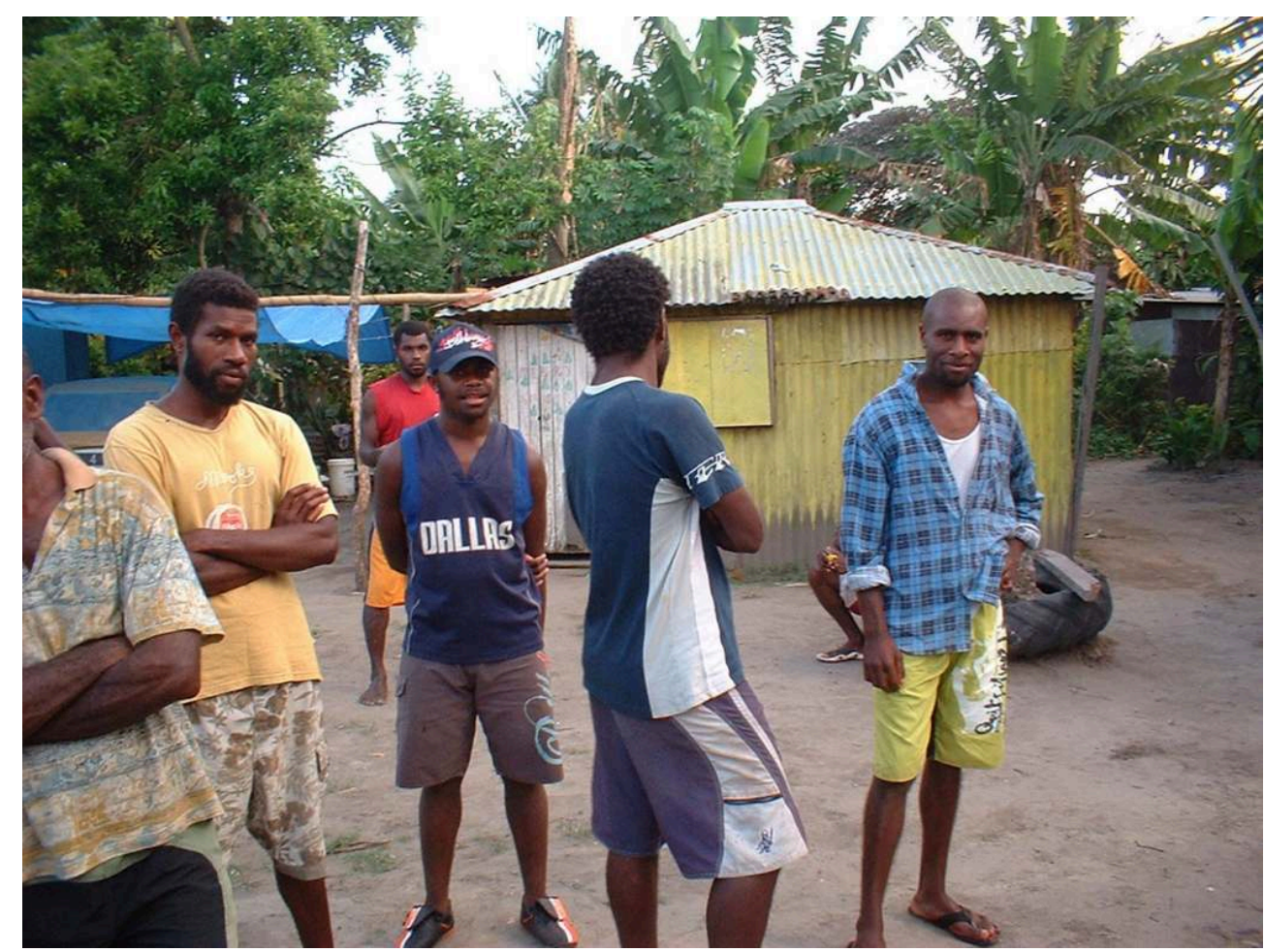

(C) Lamont Lindstrom)

10 Urban settlements are both like and unlike island villages. Tannese migrants in Blacksands, Ohlen, Erakor Hafbrij and other Port Vila settlements typically live together in extended family clusters, as kinfolk come and go from island to town. Settlers bring with them notions of a proper community and they try in various ways to model urban settlements after island villages. They arrange topography as far as this is feasible; they plant urban gardens; they bestow island names on town places; and so on (Lindstrom, 2011a).

11 Life in town, though, is notably challenging. People from across the country live contiguously in diverse and jumbled clusters. Residents of adjacent settlement clusters may be fellow Tannese migrants, but just as likely they come from elsewhere, and these assorted neighbors typically lack the kin ties that make village life smooth (Lindstrom, 2011b: 20). Most of my Tanna friends also have no title to the land on which they have built timber and sheet metal shacks, except for a few who have purchased house plots in Freswota where lots are smaller than in some settlement clusters elsewhere, with more people squeezed into less space. Matu, who has lived in Freswota for fifteen years or so, has localized her house plot by naming this 'Ainsle', after her son, but she also complains that living in Freswota is like being sentenced to the kalabus ('jail'), imprisoned there by constricted space and impinging neighbors.

12 Settlement life can be nerve-racking. Away from home villages, migrants notably worry about respect. If only there was more of this, urban life would be easier. For example, noes (or taragaru), an interview keyword, expressed people's unease with urban messiness and disorder. The fairly recent emergence of the word tanak, 'thank you', also suggests an emerging urban etiquette that reflects increased concerns to enhance often awkward neighborly relationships and to urbanize patterns of island reciprocity. 
Missionary wife Mary Matheson, on Tanna in 1860, observed that her island neighbors "do not seem to have any word for compassion, and there seems to be no such emotion within them. There is no word expressive of gratitude" (Patterson, 1864: 466). Matheson was wrong about emotive compassion, but right that expected and obligatory reciprocity makes verbal expressions of gratitude superfluous. The neologism tanak adds a level of verbal reciprocity to assuage often tense urban relationships.

Conflict, sometimes serious, occurs back in home villages too although people there have familiar and ready routines and strategies to deal with this. In town, while living among neighbors who are not kin, urbanites entertain heightened suspicion of one another's motives. They worry, in particular, about new sorts of envy and jealousy,jalus in Bislama, that kindle gossip, conflict, and even sorcery (nakaemas). Reporting from Luganville, Vanuatu's second town, Taylor noted an "unsettling backslide into urban disorder" caused by

"the ethnically mixed nature of life in town, increasingly difficult and competitive economic conditions, and a resulting climate of jelus (jealousy)." (2015:39) Migrants often presume that jalus sorcery is likely behind puzzling illnesses or freak misfortunes, which are common enough in Vila's rough settlements. Migrant worry bubbles along in these anxious sorcery undercurrents (Rio, 2010, 2011), and underlying angst has occasionally burst forth in violent confrontation (Mitchell, 2000, 2011).

Worried about sorcery and possible and actual conflict, migrants have speedily embraced notions of sekiuriti - extending this from its original English reference to label growing numbers of guards and watchmen who surveille town stores, clubs, and cash machines, to more general notions of how to deal with potentially dangerous settlement turmoil. In Luganville, for example, many urban migrants

"are understood to recruit and surround themselves with human sekiuriti (security), a term than not only includes the hired protection of physical muscle, but also kleva [spirit mediums] and other spiritually powerful individuals to protect them from the potential sorcery attacks that through relational logic their positions are seen to intrinsically attract." (Taylor, 2015: 47)

Alongside beefing up sekiuriti, migrants have also generated a ubiquitous respek discourse, demanding respect in their relationships and bemoaning its absence in hopes of improving the odds of urban survival. Like sekiuriti, respek's semantics are also multilayered. On Vanua Lava, for instance,

"If respect is breached several things may happen [...] the disrespectful person might have an accident." (Hess, 2009: 29-30)

Sekiuriti and respek are both spiritually patrolled. Lack of respect (as can brute jealousy) may boomerang back upon the disrespectful.

Although Bolton (2003: 4) found at least one word for 'respect' in all indigenous languages of Vanuatu (see Vanuatu Cultural Centre, 1999; Lerche, 2008: 5), people codeshift freely between Bislama respek and indigenous terms. When discussing respect in Nafe language, southeast Tanna migrants use the word nisiaiien (the noun, or siai the verb). This, today at least, does connote something like respect (as in sasiai nekava, 'we respect kava [by attending to usage protocols]'), but it can also signify 'failure' or 'inability' as in the truck risiai the hill, 'the truck was unable to climb the hill'. Nisiaiien's semantic roots likely have been shaded by 150 years of Christian usage. Missionary Bible translator William Watt used the word instead to mean 'honor', as in his $19^{\text {th }}$ century translation of the fifth commandment: 
Tikisiai remam rihnam, ma napen seim rebuk ia tuprana Iehova Atua seim raveipehe mik ['Honor your father your mother, that your days will be many on earth your Jehovah God gives to you'] (Anonymous, 1941: 15)

\section{Testament, Watt only once translated this using}

siai: kemyaha hi-epesiai ketir kavegi in ya tenari amasan ['you all then respect a person dressing himself in good cloth']

or, in the King James version,

'And ye have respect to him that weareth the gay clothing' (James, 2:3)

Respek blurs semantically with honor - but is such honor due to individual persons, or to designated authority (one's parents; that gay clothing)?

Tanna migrants bemoan respect's absence but they evoke it constantly to explain urban conflict and various disappointments. Good Melanesians, their worries focus more on fragile social order in the settlements than on problems of precarious personal honor, dignity, or esteem, although, here too, urban economic disparity and escalating "incommensurate differences" (Gewertz and Errington, 1999: 42) increasingly injure one's personhood, however construed. In 1970s Port Moresby, for example, unskilled migrants found honor mostly among their wantoks while the better educated found "respect in interaction with both wantok and outsiders" (Levine and Levine, 1979: 91). Back home on Tanna, people do also evoke and claim respect. Nafe siai, however, may not completely overlap a more semantically expansive Bislama respek insofar as island interpersonal relations are more predictable and manageable. My guess is that that respect talk and respect claims have multiplied in Vila's settlements as migrants encounter new sorts of inequality and relational volatility.

I excerpt English translations of urban respect talk from interviews with five Tanna migrants (see Appendix). In these, migrants connect respect to problems of community, to leadership, control and access to scarce resources, and family responsibilities. Comparing town with village, migrants complain that urbanites lack respect in general. Uri, from Freswota 4, grumbled:

"Living on Tanna, we all have respect, we all have lots of love. There is peace [and quiet] on Tanna. But in Vila, respect is small. Love is small. Peace is small."

Iapwatu, from Ohlen Nabanga, said much the same:

"There is no respect here in Vila. No respect. Perhaps on Tanna, kastom and the church, the two establish respect. But you come and live here in Vila and town life [has] no respect."

Soarum, likewise, from Ohlen Freswin agreed:

"If people have no respect, no respect, who is honored? Or if you don't respect others, you injure people, and people don't respect you. No respect, respect [nisiaiien] has disappeared."

Lack of respect loosely explains a range of urban troubles.

"No respect. People do any kind of thing, people steal, people kill one another, people smoke marijuana. People follow ways that aren't correct" (Soarum)

Soarum complained in particular about those who sneak food and firewood from one's urban gardens. Back on respectful, if idealized, Tanna, anyone in need of something would first ask a landowner's permission. In urban Vila, this sort of respectful and caring exchange breaks down:

"People go in all directions. Your land? I check there, and a man has gone onto your land. Some don't have your permission, some don't steal. I have noticed this. Taking something from your land, or do something, or clear bush as on Tanna. A person 
just goes all about and clears land [for a garden]. On his own, he goes on his own to clear a garden. Do that and trouble will rise, will arise now. That man, as I say, doesn't respect, he doesn't respect a person's property or his things. Doesn't come to ask, but just goes to look for trouble. If he does this, and you challenge him, you two will fight you two, and you will live in trouble." walked home through ohlen with two young men delegated to look after me - their parents nervous about the risks of an evening stroll through the settlement. Sputtering and shouting incoherently (at least to me), an angry mugger came up from behind and slugged one of the boys in the face leaving him bleeding from his cheek. This was a neighbor, also from Tanna but from the White Sands area, who was angry that my friend's son had broken a plate on which the assailant accidentally cut his foot - or so went the story people were willing to share with me. Both families involved called in their town chiefs, and they summoned neighbors to three successive disputesettlement meetings, but all to no avail in that the assailant's party refused to attend any of these.

Much respect talk bemoans urban female dress. In recent years, an ongoing traosis debate - whether or not young women can properly wear pants - has waxed and waned in Port Vila (Cummings, 2013). My impression is that urban women have won the trouser wars, but migrants still grouse about the respectful messages of female dress. Glenda, for one, complained:

"Life has become very difficult. Before, before there was respect. Before you went to town and saw a woman, you knew she was a woman; you went to town and saw a man you knew he was a man. But today, it's like that song Naio sang, "Babylonian 
Style." 3 You see a woman and don't know she's a woman. She turns and looks towards you and then you notice her breasts. And all kinds of clothing."

Soarum echoed Glenda's complaint:

"Women wear trousers, women have no respect for others today. Life has become bad. Life has become bad, not good."

And so did Iapwatu:

"No respect, it's serious, clothing is not good. No respect here in Vila." with tasteful dress. Under a "Respect" subheading, the site warns the careful tourist to mind her clothing:

"Throughout Vanuatu, and especially outside of Port Vila in the villages, life is strongly influenced by "kastom" - a set of traditional customs and taboos that apply to all kinds of matters. Be aware of this, and respect locals' requests with regard to "kastom". When visiting villages, women should dress modestly, wearing clothes that cover the shoulders and knees... Revealing and sexy clothing (especially wearing beach wear in the capital) is not advisable, as over 100 years of missionary work has had its effect on the perception of what is considered as respectable attire in the islands. Regardless, it's considered disrespectful to the local people and can be interpreted by some indigenous inhabitants as an invitation for sex" (en.wikivoyage.org/wiki/Vanuatu, accessed $1^{\text {st }}$ March 2016)

31

My guess is that complaints about proper dress float on deeper waters. This is nervousness about family responsibility (and, yes, this includes sex) in new settlement contexts where everyone works for money if he or she possibly can. Wives, thus, sometimes out-earn their underemployed husbands. Kids run wild and who knows what daughters are up to? They parade about town in trousers or worse. Urban fathers fight losing battles to uphold Tanna marriage custom that demands parent-arranged sister-exchange agreements between families. Worries about disrespectful dress key larger concerns about urban family dynamics. These comments intersect with other worries about fri, about the negative facet of freedom, when persons disconnect from their family duties. Respect worry also intersects with pervasive nervousness about the ubiquitous mobael or cell phone and how this, too, allows personal independence as much as it facilitates connection (Anderson, 2013). Again, many of these worries center on young women using mobael telephones to reach out to boyfriends and suitors, circumventing parental control (Kraemer, 2017; Taylor, 2016).

Understandably, urban migrants express ambiguous appreciation of fri. Soarum, for instance, recalled that he felt like a "slave" working for unELCO, Port Vila's electric company. He had no control over work hours and he had to mind a meddlesome boss. He left that job and bought a taxi seeking more freedom, more fri. This sort of fri is a good thing. On the other hand, urban freedom can allow migrants to wiggle out of responsibilities and duties to support their family and neighbors, especially when these come seeking money. Children, too, take advantage of urban opportunities to evade parental control. They wander about; they dress flamboyantly and twist their hair into flashy styles; they whisper into phones seeking romance; they don't listen. Creeping fri, thus, is a fundamental cause of intensifying urban sentiments of disrespect and of escalating calls to restore respectful relations.

Migrants encounter freedom and disrespect in Vila's settlements but ultimately many modern turpitudes have originated abroad, as Iapwatu argued:

"Respect is lacking here because people live according to town life, copying the Western style life of white men. It came to this place and made respect disappear." 
Glenda likewise cited disrespect's foreign roots:

"People are trying to adopt a lifestyle, they are adopting a lifestyle than comes from overseas. I say it's like the foreigners live."

But will urban disrespect spill from settlement down into Tanna's harmoniously perfect villages, too? Uri, who has lived in Vila the longest, imagined the island still to be a paragon of peace and quiet:

"Living on Tanna, we all have respect, we all have lots of love. There is peace [and quiet] on Tanna."

Iapwatu attributed enduring island respect to the influence of church and kastom:

"Perhaps on Tanna, kastom and the church, the two establish respect."

Soarum, though, had his doubts. Disrespect, he fears, has already spread from town to village:

"It's like that here, really like this in Vila but also on Tanna, it's the same, the same. It's the same in other countries, and Vanuatu too. People have adopted those ways; they have adopted town fashion, and taken this back to the island, it's the same. We have taken on that life today, one fashion, only one fashion. However one lives here in town, it's the same on the island."

Disrespect's genealogical progress thus begins overseas, invades urban Port Vila, and now is even tainting island homes where local respect worries grow as new sorts of economic and incommensurate differences spread from town back to island. In Vila's settlements and now even in home villages, respect discourse precipitates into and informs an emerging national culture. Even if respect is often sorely lacking, since 1980 respek has become a shared national value and a useful strategy for creating a broader community.

\section{Respect and National Culture}

Especially in its absence, respek is a central ethic in ni-Vanuatu urban culture which is increasingly also Vanuatu's national culture. Respect talk pervades urban and national discourses beyond the migrant settlements. It adorns Vanuatu's constitution in its chapter Fundamental Rights and Freedoms of the Individual, one of whose fundamental duties is

"to respect the rights and freedoms of others and to cooperate fully with others in the interests of interdependence and solidarity" $(7(f))$; and a child, furthermore, is

"to respect his parents" (7(i)).

The country's justice sector agencies, including the Department of Correctional Service, boast the motto

"Sefti, digniti, rispek mo gud fasin blong evriwan [Safety, dignity, respect and good manners for all]." 
Figure 2. - Nationalist respek on the Dept. of Correctional Service's front door, Port Vila, 2016

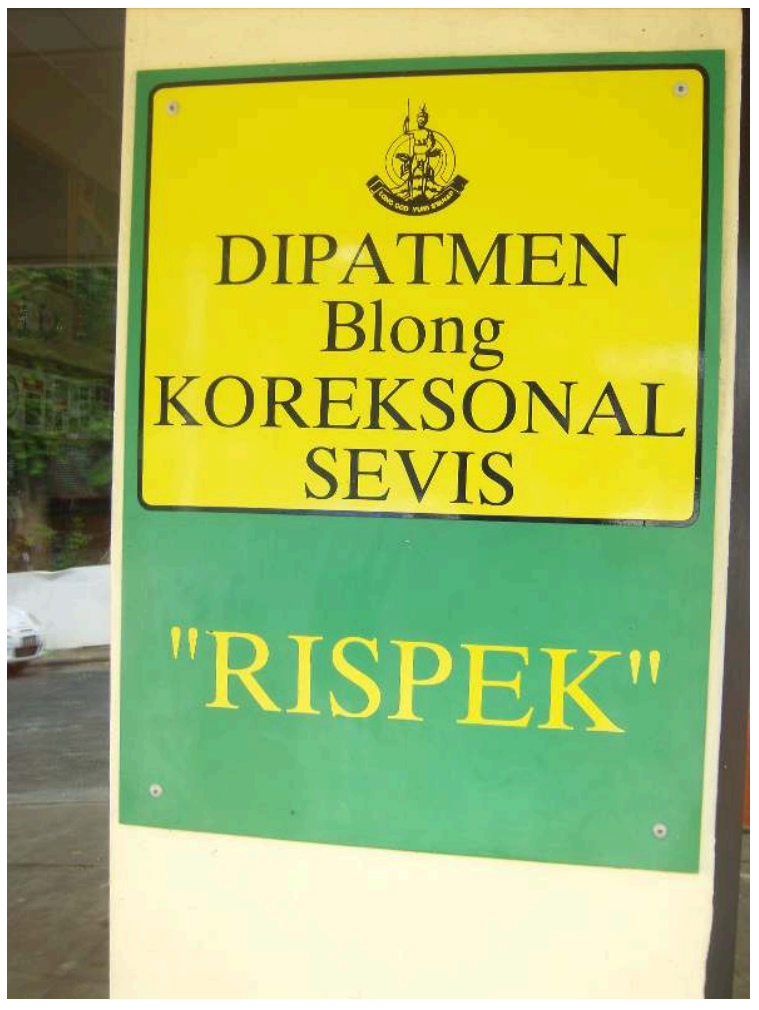

(@) Lamont Lindstrom)

37 Vanuatu's first Prime Minister, Walter Lini (who died in 1999) is still regularly celebrated for his now often repeated catchphrase, "Respect is Honorable." This has popped up in many unexpected places, including the Vanuatu Tourism Office's Facebook page, an address by the Chinese Ambassador, Malapoa Secondary School celebrations, development consultancy reports, and even a Port Vila Airbnb listing. The phrase originated in a conclusion that Lini contributed to a 1980 book which celebrated Vanuatu's recent independence. Contemplating the new nation's future, Lini wrote:

"We believe that small is beautiful, peace is powerful, respect is honourable, and

community is both wise and practical for the people of Vanuatu." (Lini, 1980: 290)

Few also acknowledge his associated appreciation of smallness, peace, or wise and practical community. Honorable respect instead commands nationalist memory.

Respect talk fills public venues beyond official discourse. The newspaper Daily Post's online archive records more than 500 instances of "respect" (or respek or rispek) published from April 2014 through May 2015 (although some of these are the prepositions "in respect of" or "with respect to"). Respect turns up in headlines, as in a report about former President Iolu Abbil's speech to open Parliament:

"President: Teach youth value of respect and loyalty." (30 May 2014)

President Abbil reminded MPs and the nation "about the importance of instilling youth with the value of loyalty and respect." Respect frequently crops up in news coverage and commentary. For example, Vanuatu's Senior Biodiversity Officer, herself respected, advocates respect for flying foxes and birds:

41 The highly respected Biodiversity Officer says, 
"It is important for people to know that such wild life's homes and food are also affected like us humans therefore people must respect them not to hunt them." (23 March 2015) echoing the Bislama dictionary's prototype usage. Former Prime Minister Natuman, originally from West Tanna, counted up five "kastom principles or values" that would shape his government, these the "golden N-rules" (many nouns in Tanna languages start with ' $n$ '). The second of these golden rules is, indeed, nisiaiien

which stands for 'respect'. Significantly, this principle was strongly advocated by Vanuatu's founding fathers, including Fr. Walter Lini who famously stated, "respect is honourable". If we have respect for ourselves, our neighbours and our communities, there won't be any need to waste valuable scarce resources on policing crime in the urban centres," he says (14 June 2014) ${ }^{4}$

In March, 2016 a second Prime Minister likewise urged

"the citizens of Vanuatu to continue to support and respect the work of the chiefs in all communities up and down the country,"

after himself receiving gifts of a mat, a pig, and kava as a "customary sign of respect" (Ligo, 2016).

Alongside Vanuatu's Presidents and Prime Ministers, lesser leaders and chiefs also regularly advocate respect - especially, respect for kastom:

"Organize the young boys and girls to come together and teach them the traditional values such as respect, public speeches, traditional cooking, weaving of custom mats and baskets, traditional dances, chants, custom stories and legends, history of their islands, traditional leadership skills and much more," Chief Worwor appeals (5 March 2015).

Chief Abert Moses Mariasi, likewise, lauded 84 new chiefly resolutions that he and other Tongoa chiefs drafted. This, he suggested:

"is a guide that will also help our young generation in many ways such as appreciating our cultural way of life, respect for one another, respect for our island and people, learning important traditional ways of life and as far as leadership, unity, peace, traditional reconciliation process, customary marriage ceremonies and the whole traditional way of life and all its customary legal systems and more" (6 April 2014).

Letters to the Editor also constantly invoke the need for respect. Man-kam (Bislama for 'migrant'), for example, a "Port Vila Residen" wrote to demand respect for local cultural sites near Freswota:

"Yumi ol man-kam yumi mekem inaf damej finis long ol kaljoral site blong ol man ples.

Yumi respektem olgeta from yumi stap long nasara blong olgeta. No go tumas long stael blong whiteman from stael ya hemi blong self destruct nomo. [All we migrants have already damaged local people's cultural sites. We respect them [the local people] because we live in their nasara [village dance grounds]. Don't overly follow white man's style because that style is just self-destructive.]" (31 January 2015).

Another wrote to protest rape, demanding respect for women and girls:

"Be igud blong ol lida long komuniti i toktok long ol yangfala mo ol olfala blong oli rispektem ol woman mo gel" [But it's good that all community leaders instruct youth and elders to respect women and girls] (15 April 2014)

I could go on. 
Respect talk spills over into other media beyond newspapers. Some ni-Vanuatu email fans acclaim respect in mini epigrams in the signature files that finish off their messages, as did one Anderson Ismael on 5 February 2015:

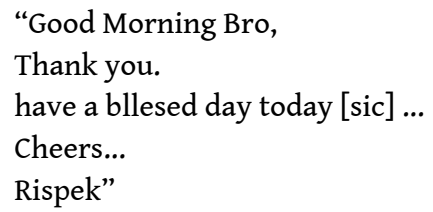

Contributors to Vanuatu Facebook groups like Yumi Toktok Stret also regularly invoke the need for more respect/respek or deplore the lack thereof. Daily postings to that Facebook Group evoke loss of respect or demand more of it. Abel Nako, a member of Vanuatu's small literary community, has co-written a romance of respect: Vanuatu: A Tale of Respect and Unity (Jensen and Nako, 2014). In this, chiefly wisdom and kastom values instill Ambae youth with "respect for their parents and to grow up in line with established values" despite their alienating boarding school experiences (Daily Post, 5 March 2015). NGos, too, headquartered in Port Vila cultivate Vanuatu's respect discourse. Those groups pushing gender equality and fighting domestic violence have embraced respek to advocate for women's rights and more peaceful families (Tor and Toka, 2004: 14; Lerche, 2008: 11-12). In 2014, UNICEF funded a "Respect Van" as part of a school antibullying program. The Respect Van drove around to every school in Port Vila and Efate. As part of the campaign, UNICEF commissioned a song, "Respecting One Another," from local musician Stan Antas. Preaching the need to "Leftem Up Rispek," its first verse concludes:

"Remember this: Se mi mi olsem yu, yu yu olsem mi/We got to respect one another, respect one another."

These nationalist, journalistic, and organizational treatments of respect complement and reinforce everyday respect chatter among urban migrants living in Vila's settlements. Altogether, they contribute to growing national certainty that Vanuatu is - or at least should be - a respectful place.

\section{Respectfully Yours?}

51 Tanna migrants in Vila habitually assess town life as difficult, particularly when comparing urban experience with life back home in island villages. Kieri's many complaints are typical:

"I see that life in Vila is tough. Tough, if you want to live, if you want to stay, you must work. Because of vatu [money]. And if you don't work, it's kind of tough for you. Transportation, it's like that, life in Vila. You want to sleep, you must give money. You pay for a house, you pay for light, pay for water, you get food with money, if you go to the toilet you pay!"

What once was fri on the island is marketable in town. Respek discourse accompanies Kieri's typical Port Vila money grumbles. Respek indexes urban unhappiness over the erosion of gift-giving and demand-sharing among kin and neighbors. It indexes nervousness about neighborhood conflict, and worry about persons who dodge island responsibilities. If tanak asori ('big thanks') is indeed a post-contact invention, Tannese in earlier days may not have felt much obligated to recognize someone merely for 
upholding his or her expected exchange obligations and normal gift-giving. And, even today, those who respond with this courtesy only offer each other a big tanak, and do not lexically thank the singular, personal you involved.

Respect talk amplifies alongside individualism not because urban migrants, like second-rate American comics, insist on this but because people desire to sustain community and more relational sorts of personhood. Migrant respect talk still targets a person's relational responsibilities that span village and town even if urban hardships and opportunities are eroding these. Not many possessive individuals of the Western variety, demanding respect for their singular and marvelous differences, yet inhabit Port Vila's urban settlements. Not so much respectfully yours, respectfully mine, or even respectfully ours, the urban command is to honor and respect respek itself. Respect serves as a marker - a canary in the urban coalmine - of the current strength and viability of traditional expectations of persons and of their relationships; and such relations that conjoin parents and children, husbands and wives, and people and jifs are intrinsically hierarchical. Respek certainly sustains these inequalities, or tries to. It keys ideals of cooperation and relational identity that urban experience now threatens and corrodes.

"It is both appealed to in its absence and decried in its abuse." (Lerche, 2008: 16)

Respek thus is the antidote, so people hope, to creeping individuality, troublesome freedom, and personal selfishness. Demanding respect is therapeutic; a potential though increasingly ineffective cure for conflict within and among migrant families.

Likewise, in wider arenas beyond the settlements, respect talk evokes an envisioned national community. Respect properly leads to national unity, consensus, and stability. Calls for respect are utopian but also strategic as a 17 May 2015 Facebook posting by Robson S. Tigona implies:

"Respect the law every one whether police or civilians blo mekem Vanuatu come wan 'golden state' [...to make Vanuatu into a 'golden state']."

Those quotation marks suggest that the perfect, "golden state" remains aspirational, but the command that everyone must have respect points the way to get there. Recent nationalist epitomes of the ideal community borrow and build on people's everyday urban respek worries and claims.

These amplifying and noisy demands for respek, however, should trouble Vila's urban migrants. The more people insist on respect, the less they are finding. Emerging urban culture undermines the customary conditions for respek as it promotes ever more noisy demands for it. As respek continues to dissipate, as Soarum put this, urban migrants "go in all directions." While travel from village to town requires only a single journey, many migrants in town find settlement life to be uneasy and multifarious. They continue to hope that respect harmonizes their travels. 


\section{BIBLIOGRAPHY}

ANDERSON Barbara, 2013. Tricks, Lies, and Mobile Phones: 'Phone Friend' Stories in Papua New Guinea, Culture, Theory, and Critique 54, pp. 318-334.

ANONYMOUS, 1941. Naresien em Nujpume ia Nafwakien ia Nagkierien Kwamera, in Nupume em Napuanmen mine Nabukmin, Kyneton, VICT, Armstrong Brothers.

BENNETT Tony, Lawrence GROSSBERG and Meaghan MORRIS, 2005. New Keywords: A Revised Vocabulary of culture and Society, Oxford, Blackwell Publishing.

BOLTON Lissant, 2003. Unfolding the Moon: Enacting Women's Kastom in Vanuatu, Honolulu, University of Hawai'i Press.

BOURGoIS Philippe, 2003 ( $2^{\text {nd }}$ ed.). In Search of Respect: Selling Crack in El Barrio, Cambridge, Cambridge University Press.

CROWLEY Terry, 1990. An Illustrated Bislama-English and English-Bislama Dictionary, Port Vila: Pacific Languages Unit, University of the South Pacific.

CUMmINGS Maggie, 2013. Looking Good: The Cultural Politics of the Island Dress for Young Women in Vanuatu, The Contemporary Pacific 25, pp. 33-65.

GEWERTZ Deborah B. and Frederick K. ERRINGTON, 1999. Emerging Class in Papua New Guinea, Cambridge, Cambridge University Press.

GUY J. B. M., 1974. Handbook of Bichelamar/Manuel de Bichelamar, Canberra, Dept. of Linguistics, Research School of Pacific Studies, Australian National University, Pacific Linguistics C-34. HABERKORN Gerald, 1989. Port Vila: Transit Station or Final Stop: Recent Developments in Ni-Vanuatu Population Mobility, Canberra, National Centre for Development Studies, Australian National University.

HESS Sabine C., 2009. Person and Place: Ideas, Ideals and the Practice of Sociality on Vanua Lava, Vanuatu, Oxford and New York, Berghahn Books.

JENSEN Karin and Abel NAKO, 2014. Vanuatu: A Tale of Respect and Unity, Self-published with CreateSpace (an Amazon print house).

KIM Yol-kyu, 2005. Uncovering the Codes: Fifteen Keywords in Korean Culture, Fremont, CA, Jain Publishing Co.

KRAEMER Daniela, 2017. 'Do you have a mobile?' Mobile phone practices and the refashioning of social relationships in Port Vila Town, The Australian Journal of Anthropology 28 (1), pp. 39-55 (http://onlinelibrary.wiley.com/doi/10.1111/taja.12165/full).

KRAEMER Daniela and Margaret RoDMAN, 2007. “Conclusion”, in Margaret Rodman, Daniela Kraemer, Lissant Bolton and Jean Tarisesei (eds), House-Girls Remember: Domestic Workers in Vanuatu, Honolulu, University of Hawai'i Press, pp. 143-151.

LAWRENCE-LIGHTFOOT Sara, 1999. Respect: An Exploration, New York, Perseus Books.

LERCHE Stephanie, 2008. Rispek in Vanuatu: Negotiations of Difference and Equality, Unpublished paper presented at Australian Political Studies Association Conference, Brisbane.

LeVINE Hal B. and Marlene wolfZAHn LeVIN, 1979. Urbanization in Papua New Guinea, Cambridge, Cambridge University Press. 
LIGo Godwin, 2016 (10 March). "PM: Greatest challenge to our culture is external culture,"

Vanuatu Daily Post.

LINDSTROM Lamont, 1997. Chiefs in Vanuatu Today, in Geoffrey White and Lamont Lindstrom (eds), Chiefs Today: Traditional Pacific Leadership and the Postcolonial State, Stanford, Stanford University Press, pp. 211-228.

-, 2011a. Vanuatu Migrant Lives in Village and Town, Ethnology 50, pp. 1-15.

-, 2011b, Urban(e) Tannese: Local Perspectives on Settlement Life in Port Vila, Vanuatu, Journal de la Société des Océanistes 133, pp. 18-29 (https://jso.revues.org/6461).

LINI Walter Hadye, 1980. The Future, in Vanuatu: Twenti Wan Tingting blong Team blong Independens, Suva, University of the South Pacific, Institute of Pacific Studies, pp. 282-291.

Mitchell Jean, 2000. Violence as Continuity: Violence as Rupture, Narratives from an Urban Settlement Vanuatu, in Sinclair Dinnen and Allison Ley (eds), Reflections on Violence in Melanesia, Canberra, Hawkins Press and Asia Pacific Press, pp. 189-208.

-, 2011. 'Operation Restore Public Hope': Youth and the Magic of Modernity in Vanuatu, Oceania 81, pp. 36-50.

PATterson George, 1864. Memoirs of the Rev. S. F. Johnston, the Rev. J. W. Matheson, and Mrs. Mary Johnston Matheson, Missionaries on Tanna, Philadelphia, W. S. \& A. Martien.

RIO Knut, 2010. Handling Sorcery in a State System of Law: Magic, Violence and Kastom in Vanuatu, Oceania 80, pp. 182-197.

-, 2011. Policing the Holy Nation: The State and Righteous Violence in Vanuatu, Oceania 81, pp. 51-71.

SCHRAm Ryan, 2015. Notes on the Sociology of Wantoks in Papua New Guinea, Anthropological Forum 25, pp. 3-20.

STRATHERN Marilyn, 1988. The Gender of the Gift: Problems with Women and Problems with Society in Melanesia, Berkeley, University of California Press.

TAYLOR John P., 2015. Sorcery and the Moral Economy of Agency: An Ethnographic Account, Oceania 85, pp. 38-50.

-, 2016. Drinking Money and Pulling Women: Mobile Phone Talk, Gender, and Agency in Vanuatu, Anthropological Forum 26, pp. 1-16.

TOR Roselyn and Anthea TОКА, 2004. Gender, Kastom and Domestic Violence: A Research on the Historical Trend, Extent and Impact of Domestic Violence in Vanuatu, Vanuatu Department of Women's Affairs.

VANUATU CULTURAL CENTRE, 1999. Kastom Fasin Blong Respect: 1998 Woksop blong ol Woman Filwoka, 12-24 Oktoba 1998, Port Vila, Vanuatu Cultural Centre.

WILLIAMS Raymond, 1967. Keywords: A Vocabulary of Culture and Society, New York, Oxford University Press.

\section{APPENDIXES}

Partial Interview Transcripts

1. Harry Iapwatu (Ohlen Nabanga, but often resident in Samaria, Tanna) 
Nisiaiien riuan u iFila. Nisiaiien riuan. Rosi fwe Ipare, kastom mene nafakiien, krauni nisiaiien. Mata ikvehe mara $u$ iFila mata laef sai taon nisiaiien riuan. Nisiaiien riuan, rasori, dresing me napwah namasanien. Mua nisiaiien riuan $u$ iFila.

Nisiaiian rouihi iesa te narnah mua hamara ia laef sai taon mamo kopiaot ia Western Style ia naraien sai nipitoga a. Ravehe ia kwopen i na ro pen sai nisiaiien ramiuan. Nisiaiien ramiuan te nepran me neraman me iraham pam.

There is no respect here in Vila. No respect. Perhaps on Tanna, kastom and the church, the two establish respect. But you come and live here in Vila and town life [has] no respect. No respect, it's serious, clothing is not good. No respect here in Vila.

Respect is lacking here because people live according to town life, copying Western style life of the white men. It came to this place and made respect disappear. There is no respect for women or men, or everyone.

2. Soarum Isaac (Ohlen Freswin, 1987-1914)

Mata takwtakwni mesite pehe nah iou iakata nisiaiien riuan Monty. Nisiaien riuan. Nermama iraha hamo apenapen nari, nermama iraha hamakres, nermama iraha hamouasi apune nermama, nermama iraha hamase marijuana. Nermama iraha hamo way me nepwun rapwah namwhenien. Nepran fwe tui iraha hapukamuven mha ia traosis. Mata takwtakwni iesa, iesa iako kamparem 1987 mesite 2014 u, nepran iraha hamuven ia traosis, nepran iraha nisiaiien riuan mwi tenraha takwtakwni. Naraien renameraha. Naraien renameraha rapwah namasanien.

Ro nari ianaha i mua, rosi mua te nepen riti kamaha tahavehe mho amwhen ia kamiaha, ia kaontri me sakamiaha rosi Amerika ua paku, Australia ua iken Europe ua paku trabol ramo hapen iken, ho mua Vanuatu trame eraha, trapwah namasanien. Mata nisiaiien renamiuan, nisiaiien renamiuian.

Fwe kupwan ramasan, mata takwtakwnu, in i iakuvni raka, nisiaiien Monty, nisiaiien riuan. Nisiaiien riuan. Ierman in ramo pen ia iermama. Ikurkuren a? Na iako ting mua kamaha $i$ ia Vanuatu renamo lusum ia nari nah. Namo lusum ia nisiaiien. Nari riti sai Prime Minister sakamaha Father Walter Lini ramani ua, iahamuvahi independen. Nagkiariien asori iti, nagkiariien savani. In rani ia naha i mua respek, hemi honorable. Ikurkuren. Mata tenua iermama napwah noien respek, nisiaiien rapwah nisiaiien, tro honorem ia si? Ua tenua ikapwah noien respektem ianiram, ikamotukun pen nermama, nermama napwah noien respektem ianram. Respek namiuan, nisiaiien renamiuan.

Na iou iakata naha fwe ia taem naha, ia 1987 iahamuvahi independen ia 1980. Mata 1987, ik ikurkuren, mesite nah takwtakni iakata nisiaiien renamiuan. Neramama iraha hamaven apenapen a. Saim tuprena? Iou iakavehe fwe, iermama iti in raven men fwe saim tuprena. Nepwun hapwah nuvahiien [permission], nepwun hapwah naresien. Mua iou taken pen naha. Muvahi nari riti ia saim tuprena, ua tako nari riti, ua takarai rigi nei me riti, ramwhen ia hamo wok fwe Tanna. In reven apenapen a, marai. Reven atukw a, reven atukw a marai. Ro ia naha $i$ trabol rauta renauta takwtakwnu. Iermama, in a iakuvni, in rapwah nisiaiien, in rapwah nisiaiien neramama savani nah property ua, savani nah narimnari. Trapwah naniien marari, mata in ro a men matui trabol. Tenua ren mo, ik ik tikni, kamirau irauouasi kamirau mi, ua tirauara ia trabol. Nisiaiien riuan. Na iou iakata ia 1987 mesite 2014, nisiaiien riuan. Takani ia naha i mua nisiaiien riuan mata ia trabol mene narimnari me. Nema asori puk anan, mata nisiaiien riuan. 
Ramo iesa $u$, rosi iFila rasori na mata fwe ia Tanna ramo mui a, ramwhen mui a, ramwhen mui. Mata in nah rupukwo mha kaontri apa riti, Vanuatu i. Nermama iraha havahi mho adoptem ia way; ua iraha hamuvahi fasin sai taon, mherupen bak fwe aelan, ramwhen mui a. Mene samauta ia naraien naha takwtakwnu, i naraien kwati a, naraien kwati a. Nafe ramara iesa $i$ taon, fwe aelan ramara mui ira.

But now, nowadays, I see that there is no respect, Monty. No respect. People do any kind of thing, people steal, people kill one another, people smoke marijuana. People follow ways that aren't correct. Women in the past didn't go about wearing trousers. But today, here, here I can compare 1987 with 2014 today, women wear trousers, women have no respect for others today. Life has become bad. Life has become bad, not good.

Because of this, perhaps sometime we will become like you all, in your countries like America, or where, Australia, Europe, where much trouble happens, making Vanuatu go bad, not be good. Look, respect has disappeared, respect has disappeared.

Before it was good, but now, as I have said, respect Monty, there is no respect. No respect. A man makes trouble for people. Do you understand? I think that we in Vanuatu have lost that. Have lost respect. One thing our [former] Prime Minister Father Walter Lini said when we won independence. An important speech, his speech. He said that respect is honorable. You understand? But if people have no respect, no respect, who is honored? Or if you don't respect others, you injure people, and people don't respect you. No respect, respect [nisiaiien] has disappeared.

I have seen this from that time, 1978, we won independence in 1980. But 1987, you know, until today I see that respect has disappeared. People go in all directions. Your land? I check there, and a man has gone onto your land. Some don't have your permission, some don't steal. I have noticed this. Taking something from your land, or do something, or clear bush as on Tanna. A person just goes all about and clears land [for a garden]]. On his own, he goes on his own to clear a garden. Do that and trouble will rise, will arise now. That man, as I say, doesn't respect, he doesn't respect a person's property or his things. Doesn't come to ask, but just goes to look for trouble. If he does this, and you challenge him, you two will fight you two, and you will live in trouble. No respect. I've seen this from 1987 to 2014, no respect. I say that no respect leads to trouble with everything. Some are leading men, but they have no respect.

It's like that here, really like this in Vila but also on Tanna, it's the same, the same. It's the same in other countries, and Vanuatu too. People have adopted those ways; they have adopted town fashion, and taken this back to the island, it's the same. We have taken on that life today, one fashion, only one fashion. However one lives here in town, it's the same on the island.

\section{Uri (Freswota 4, 1992-present)}

Naraien ia Tanna, nisiaiien savahi rasori, nokeikeiien savani rasori. Namarinuien fwe Tanna. Mata sai Fila, nisiaiien rouihi. Nokeikeiian rouihi. Namariunuien rouihi.

Living on Tanna, we all have respect, we all have lots of love. There is peace [and quiet] on Tanna. But in Vila, respect is small. Love is small. Peace is small.

4. Glenda (Ohlen Freswin, 1987-2014) 
Laef ravehe mamo menekeneken puk anan. Rosi kupwan, kupwan iakani a rosi ia nisiaiien a. Kupwan ikavan ia taon mata pran, ikurkuren mua pran; ikavan ia taon mata ierman ikurkuren mua ierman. Mata ipwet mene ramhwen ia nupu riti sai Naio ramani "Babylonian Style." Ikata pran ikreirei mua pran. Truvsini a mati pehe ikata nanhen. Kani narkahuien me sapamsapa. Nermama hamo traem te nuvahiien naraien ihi, iraha hamuvahi naraien sa rakw peraha. Iakani ira rosi naraien sai nepitoga.

Life has become very difficult. Before, before there was respect. Before you went to town and saw a woman, you knew she was a woman; you went to town and saw a man you knew he was a man. But today, it's like that song Naio sang, "Babylonian Style." You see a woman and don't know she's a woman. She turns and looks towards you and then you notice her breasts. And all kinds of clothing. People are trying to adopt a lifestyle, they are adopting a lifestyle than comes from overseas. I say it's like the foreigners live.

5. Kieri Ouihi (Prima, 1980s-present)

Rosi naraien iFila iakata ianaha i mua rekeneken kwopti. Rekeneken iesa mua, tenua ikara, kani ua tikamara tikakeikei mo wok. Na mata nari vatu. Mata tenua ikapwah noien wok rekeneken ouihi tukw ik. Te navanien, mata in nah, naraien iFila. Ikua tikapri ikapri ikamri a mane. Tikaruku nimwa, ua laet ikaruku laet, maruku nui, rosi navahiien naveganien mane, tiken ia toelet ikaruku!

I see that life in Vila is tough. Tough, if you want to live, you want to stay you must work. Because of vatu [money]. And if you don't work, it's kind of tough for you.

Transportation, it's like that, life in Vila. You want to sleep, you must give money. You pay for a house, you pay for light, pay for water, you get food with money, if you go to the toilet you pay!

\section{NOTES}

1. I thank the Wenner-Gren Foundation for Anthropological Research and the University of Bergen Department of Social Anthropology's Pacific Alternatives Project for supporting field research in Vanuatu in 2010 and 2011. I am also indebted to Joel Iau, Harry Iapwatu, and other good Samaritans for their friendship and helpful conversation, as always.

2. This should be nisiaiien where [i] is a central vowel; for ease of transcription, I replace this with other (close enough) vowel graphs.

3. Naio is a popular singer with a band from Tanna.

4. The others, according to the report, are nolkeikeian ('love'), nasituan ('help; generosity'), nuparhianan ('truth; honesty') and nawitan ('goodwill; righteousness').

\section{ABSTRACTS}

Telling urban migration stories, Tanna island residents of Port Vila's settlements commonly use a number of keywords to describe life in town. I follow the "keyword" method of cultural analysis 
to approach island appreciation of urban experience. In recorded interviews, respek (respect) was one notably frequent term. Sharpening ethnic and gender identity politicking nearly everywhere has significantly boosted the term's prominence, including in socially complex post-colonial Melanesian towns. Tanna migrants bemoan respect's absence but they evoke it constantly to explain conflict and disappointment. I also consider other common urban Bislama keywords that circulate in talk about urban reality including sekiuriti (security), mobael (both telephones and Vanuatu's military force), noes (noise), jalus (jealousy), and fri (free, freedom). Keywords unlock instructive views of emergent Melanesian urbanism.

Dans leurs histoires de migration urbaine, les habitants de Tanna qui vivent dans les quartiers informels de Port-Vila emploient souvent un certain nombre de mots-clés pour décrire la vie en ville. J'utilise la méthode d'analyse culturelle dite par "mots-clés" afin d'aborder la perception insulaire de l'expérience urbaine. Respek (le respect) est un terme qui revient très fréquemment dans les entretiens que j'ai enregistrés. Ailleurs dans le monde, ce mot, souvent lié à des manœuvres politiques basées sur l'ethnicité et sur le genre, a contribué de façon importante à la prédominance de ce terme. Les migrants de Tanna déplorent l'absence de respect mais l'évoquent constamment pour expliquer les conflits et les déceptions. Je m'intéresse aussi aux autres mots-clés communs en bislama qui apparaissent dans les discussions sur la réalité urbaine : sikiuriti (la sécurité), mobael (à la fois le téléphone et les forces militaires du Vanuatu), noes (le bruit), jalus (la jalousie) et fri (gratuité, liberté). Ces mots-clés révèlent des perspectives instructives sur l'urbanisation mélanésienne émergeante.

\section{INDEX}

Mots-clés: migrants urbains, quartiers résidentiels urbains, culture urbaine, Port-Vila, Tanna

Keywords: urban migrants, urban settlements, urban culture, Port Vila, Tanna

\section{AUTHORS}

\section{LAMONT LINDSTROM}

Professor of Anthropology, Associate Dean, Henry Kendall College of Arts and Sciences, University of Tulsa USA, lamont-lindstrom@utulsa.edu 